solely for science - "but science will be well served". The political and social issues, and the possibility of eventual colonization all receive attention.

Oberg's analysis of Soviet intentions is important. If Western intelligence is correct - that they have a 14-millionpound thrust booster under test - then a Soviet two-year manned fly-by of Mars and return to Earth cannot be many years away. Only two or three of these rocket launchings would be required to assemble a spaceship in Earth orbit for a Mars landing and the long duration trends of recent Soyuz-Salyut enterprises underlines Oberg's conclusion that they really mean to send men to Mars.

Oberg's book is a timely and valuable document and it is to be hoped that the American space planners will take notice of the well-reasoned discussion. It is perhaps unfortunate that a short section near the beginning, "Scenario", reads like science fiction, but the remainder of the book is a serious scientific and technical analysis of a great adventure with which man could end the twentieth century.

Sir Bernard Lovell, formerly Director of the Nuffield Radio Astronomy Laboratory, Jodrell Bank, is Emeritus Professor of Radio Astronomy at the University of Manchester.

\section{School of leeches}

\section{Brian Mulloney}

Neurobiology of the Leech. Edited by Kenneth J. Muller, John G. Nicholls and Gunther S. Stent. Pp.320. ISBN 0-87969146-8. (Cold Spring Harbor Laboratory: 1982.) $\$ 36$, (US), $\$ 43.20$ (elsewhere).

Neurobiology of the Leech invites immediate comparison with two classics: T.H. Huxley's The Crayfish and Eric Kandel's The Cellular Basis of Behaviour. All three treat a particular animal as an entry to a broad consideration of biological problems at several levels of analysis, including the development of the animal and the physiological, the structural and the evolutionary bases of its behaviour. Neurobiology of the Leech is instructive, therefore, of the perils of editorial committees and multi-author books. It lacks the brilliant style and flashes of insight that Huxley achieved a century ago, and also the thoughtful coherence and intellectual depth that make Kandel's book such a fine contemporary introduction to neurobiology.

The ten chapters review four topics, Sawyer and Payton leading off with an introduction to the structure and behaviour of leeches. Readers should be warned that Sawyer's enthusiasm for Anderson's (1973) phylogeny is not shared by all zoologists, and not used in most textbooks, even though it may be correct. The book then gets down to neurobiological business with chapters by Blackshaw and by Stent and Kristan that describe some of the sensory and motor neurons in leeches, and describe how the nervous system makes the leech swim. These authors review well work up to 1980 , but do not provide the broader, comparative analysis that would make the book suitable for beginners. The analysis in the contribution by Stent and Kristan has also been made obsolete by new results from their own laboratories; the last paragraphs of the chapter hint at the scale of the revision that is necessary.

Synaptic structure and transmitter chemistry are reviewed in two chapters; one is a very thorough analysis by Muller that duplicates his 1979 review in Biological Reviews, the other a workmanlike review by Wallace. Together they demonstrate that, at the cellular level, leeches are like any other well-studied metazoan; they have vesicles, transmitters, receptors and gap junctions that can be studied here as well as anywhere. The chapters do not make clear that these results apply beyond this class, and should be known to all of us who study neuronal organization; the results do apply and should be familiar.

The final chapters cover the development of the leech's nervous system in embryos and the regeneration of axons and connections in adults. Weisblat's account of development is a crisp review of the lineage studies and analysis of neurogenesis and differentiation that he and others in Stent's group have conducted. The publisher, however, has served Weisblat poorly; the reproduction of his wonderful photographs achieves the quality of a tabloid on an average day, and the reader will not be able to see how exciting they are. Again, the chapter is devoid of any comparative analysis or perspective that would help naive readers.

These authors have taught a successful course, with the same title, each year at Cold Spring Harbor Laboratories. The course recruits as students advanced graduate students and postdocs, and drills them in the literature and methods of the Nicholls and Stent school. The book succeeds best as a review for the same categories of readers, graduate students revising for examinations and postdocs considering neurobiology as a career. It fails progressively as the target audience broadens, because it lacks any consistent attempt to put the neurobiology in either a comparative or a behavioural context. It is, however, an excellent summary of the activities of the Nicholls and Stent school during the past two decades, and, as a bonus, it includes as appendices a useful manual for electrophysiology of leeches and an atlas of neurons in Hirudo.

Brian Mulloney is in the Department of Zoology at the University of California, Davis.
Monkish zealots and dark anathemas

\section{Mark Ridley}

The Descent of Darwin. By Brian Leith. Pp.174. ISBN 0-00-219548-8. (Collins: 1982.) $£ 7.95$.

IF I say that Brian Leith is a $\mathrm{BBC}$ producer, and that the subtitle of his book is $A$ Handbook of Doubts about Darwinism, most British readers, at least, will be able to guess the contents: the Gouldian synthesis of anti-adaptationism, punctuated speciations, macroevolution, and structuralist embryology, philosophers on tautology, Steele's Lamarckism, and cladism; only Sir Fred is missing. Such are the ideas which, Leith believes, may be about to replace traditional neo-Darwinism. All the doubts, as Leith makes clear, are about natural selection, not evolution.

Brian Leith, the dust-jacket tells us, has "an undying admiration for Darwin, if not [it adds] for some of his disciples". And one can only sympathize. The traditional Darwinians we meet in these pages are enough to kill off anyone's admiration. They are the most terrible of people, dogmatically devoted to their unbending faith, puffed up and over-confident, now assassinating characters, now stopping up the heretic's funds, now scattering their enemies, driving them to suicide, to destitution, and even to Australia. They are at their worst with Mendelism which, Leith tells us, it is simply not possible to suggest is wrong. No wonder he does not admire them! No wonder he hands down what might otherwise be considered condescending advice! Let the Darwinians clarify what they mean by "random": let them avoid "sloppy thinking": let them rid themselves of reductionism.

We must accept, if we are to go on, that this is a partisan book. Then we can ask just how well it succeeds in explaining the controversies to its intended reader, someone who does not know about them already. It is less clear on the purely destructive criticisms of natural selection than on the constructive alternatives such as macroevolution, structuralist embryology and Lamarckism. Thus, the discussion of whether Darwinism is falsifiable could be better, although I was amused by the way Sir Karl is nearly always introduced by some such epithet as "great philosopher" or "leading twentieth-century philosopher of science". The accounts of punctuated equilibrium, and of Steele's work are generally clear, but the former does give the impression that macromutations ("anathema", we are told, to the neoDarwinians) rather than geographic speciation are the preferred explanation. A beginner, I suspect, after reading the chapter on cladism, would not know much about what it actually is; he would really have learned no more than that it is some 